\title{
PEMBELAJARAN KOOPERATIF INVESTIGASI KELOMPOK UNTUK MENINGKATKAN HASIL BELAJAR MATEMATIKA SISWA KELAS IX SMP NEGERI 1 TEMBILAHAN
}

\author{
Anita \\ Guru SMP Negeri 1 Tembilahan \\ anitasarlan@gmail.com
}

\begin{abstract}
ABSTRAK. Penelitian ini bertujuan untuk meningkatkan kemampuan hasil belajar matematika siswa IX dengan penerapan pembelajaran kooperatif investigasi. Subjek penelitian adalah siswa kelas IX SMP Negeri 1 Tembilahan berjumlah 32 orang. Penelitian ini merupakan penelitian tindakan kelas dengan penerapan langkah-langkah pembelajaran kooperatif investigasi yaitu: 1) Pendahuluan yang terdiri dari mengondisikan siswa untuk siap belajar,menyampaikan tujuan pembelajaran, memberikan motivasi, memberikan penjelasan tentang model pembelajaran yang digunakan. 2) Kegiatan inti yaitu pengelompokan, siswa dibagi menjadi kelompok belajar dan pada tahap investigasi, siswa diberikan permasalahan terkait materi ajar. 3) kegiatan akhir guru bersama siswa melakukan refleksi pembelajaran dan menutup pembelajaran. Hasil penelitian menunjukan terjadi peningkatan terhadap pembelajaran siswa yaitu $77.42 \%$ pada siklus I menjadi $93.55 \%$ pada siklus II. Persentase hasil observasi aktivitas guru meningkat dari $85.33 \%$ pada siklus I menjadi $95.66 \%$ pada siklus II. Persentasi hasil observasi aktivitas siswa meningkat dari $82.44 \%$ pada siklus I menjadi $91.27 \%$ pada siklus II. Hal ini menunjukkan bahwa aktivitas guru dan siswa pada pembelajaran kooperatif investigasi kelompok berjalan dengan sangat baik. Respon siswa terhadap pembelajaran kooperatif investigasi kelompok pada penelitian ini sangat positif
\end{abstract}

Kata Kunci: pembelajaran kooperatif, Tindakan Kelas, Matematika

\section{COOPERATIVE LEARNING INVESTIGATION GROUP TO IMPROVE MATHEMATICSS LEARNING OUTCOMES OF CLASS IX STUDENTS OF SMP 1 TEMBILAHAN}

\begin{abstract}
This study aims to improve the ability of mathematics learning outcomes of IX students with the application of cooperative learning investigations. The research subjects were 32 students of class IX SMP Negeri 1 Tembilahan. This research is a classroom action research with the application of cooperative investigative learning steps, namely: 1) Introduction which consists of conditioning students to be ready to learn, conveying learning objectives, providing motivation, giving an explanation of the learning model used. 2) Activities, namely grouping, students are divided into study groups and at the investigation stage, students are given problems related to teaching material. 3) Refecting. The results showed an increase in student learning, namely $77.42 \%$ in the first cycle to $93.55 \%$ in the second cycle. The percentage of teacher activity observations increased from $85.33 \%$ in the first cycle to $95.66 \%$ in the second
\end{abstract}


cycle. The percentage of observations of student activities increased from $82.44 \%$ in the first cycle to $91.27 \%$ in the second cycle. This showed that the activities of teachers and students in cooperative learning group investigations went very well. Student responses to cooperative learning group investigations in this study were very positive

Keywords: cooperative learning, classroom action research, mathematics

\section{PENDAHULUAN}

Matematika sebagai ilmu yang terstruktur dan sistematis mengandung arti bahwa konsep dan prinsip dalam matematika saling berkaitan antara satu dengan yang lainnya. Dalam belajar matematika untuk mencapai pemahaman yang bermakna, siswa harus memiliki kemampuan koneksi matematis yang baik. Kenyataan yang terjadi, kemampuan koneksi matematis siswa masih belum baik. Hasil pekerjaan siswa dalam menyelesaikan persoalan matematika masih tidak sesuai dengan prosedur pe-nyelesaian yang diajarkan. Siswa belum mampu mengaitkan konsep-konsep yang telah dipelajari sebelumnya dalam pe-mecahan masalah yang berkaitan dengan to-pik pelajaran.

Faktor penyebab ketidakmampuan siswa mengaitkan konsep-konsep yang telah dipelajari dalam pemecahan masalah salah satunya adalah cara mengajar guru. Guru masih mengajar dengan cara lamam dengan menyajikan materi pembelajaran, memberikan contoh-contoh soal dan meminta siswa mengerjakan soal-soal latihan yang terdapat dalam buku teks yang mereka gunakan dalam mengajar dan kemudian membahasnya bersama siswa. Terbiasanya siswa mengerjakan soal-soal rutin membuat siswa tidak dapat menyelesaikan soal-soal yang berbentuk non rutin. Siswa tidak terbiasa menyelesaikan masalah secara bebas dan mencari solusi penyelesaian dengan caranya sendiri. Siswa hanya bisa mengerjakan soal-soal yang bentuknya sama dengan contoh soal yang diberikan guru. Apabila soalnya berbeda siswa mulai kebingungan.

Hal tersebut ditemukan pada siswa kelas IX SMP Negeri 1 Tembilahan. Oleh karena itu peneliti memutuskan mengadakan studi pendahuluan lapangan untuk menentukan permasalahan. Ternyata kemampuan pemahaman konsep siswa pada kelas IX.9 tersebut masih rendah, serta kemampuan siswa mengaitkan atau menerapkan suatu konsep pada operasi penyelesaian masalah tidak tepat arah.

Pembelajaran kooperatif (cooperative learning) merupakan sistem pengajaran yang memberi kesempatan kepada anak didik untuk bekerja sama dengan sesama siswa dalam tugas-tugas yang terstruktur (Suherman, dkk. 2001). Selanjutnya, Suherman menjelaskan bahwa pembelajaran kooperatif mencakup suatu kelompok kecil siswa yang bekerja sebagai sebuah tim untuk menyelesaikan suatu masalah atau mengerjakan sesuatu untuk mencapai tujuan bersama lainnya. Pembelajaran kooperatif dikenal dengan pembelajaran secara berkelompok. Namun, belajar kooperatif lebih dari sekadar 
belajar kelompok atau kerja kelompok karena dalam belajar kooperatif ada struktur dorongan atau tugas yang bersifat kooperatif sehingga memungkinkan terjadinya interaksi secara terbuka dan hubungan yang bersifat interdependensi efektif di antara anggota kelompok (Sugandi, 2002:14). Pembelajaran kooperatif merupakan strategi pembelajaran untuk melatih siswa menumbuhkembangkan kompetensi pemahaman akan perbedaan budaya sebagai landasan membangun kehidupan bersama. Kehadiran strategi ini dilandasi oleh tiga hal, yaitu secara filosofis, teoritis, dan empirik.

Landasan filosofis pembelajaran kooperatif adalah pandangan filsafat konsruktivisme, khususnya yang berkenaan dengan proses belajar siswa, proses mengajar guru, dan kondisi pembelajarannya. Dalam kaitannya dengan proses belajar siswa, konstruktivisme memandang bahwa dalam belajar, siswa harus bertanggung jawab atas pembelajarannya. Pengetahuan itu merupakan sesuatu yang bersemayam dalam tubuh siswa itu sendiri, bukan yang ada di luar siswa. Siswa akan memperoleh pengetahuan baru jika informasi yang diterima secara kognitif berinteraksi dengan sesuatu yang telah diketahui sebelumnya (Handoyo, 2004:19).

Dalam proses belajar, siswa berperan sebagai subjek yang aktif membangun pengetahuannya sendiri dengan cara mengaitkan pengalaman, pengetahuan, dan keterampilan yang ada dalam dirinya dengan informasi baru yang diterimanya. Proses membangun pengetahuan tersebut tidak dilakukan secara individual oleh siswa, tetapi dikerjakan secara berkelompok melalui pengalaman langsung sehingga hasil belajar menjadi lebih bermakna bagi siswa. Peran guru dalam proses mengajar adalah sebagai fasilitator yang memberikan kemudahan dan bantuan kepada siswa untuk membangun pengetahuannya. Untuk itu, dalam proses mengajar, guru lebih banyak menyediakan fasilitas yang memungkinkan siswa dapat membangun pengetahuannya sendiri dengan cara memadukan pengetahuan dan pengetahuan yang telah dimiliki sebelumnya dengan pengetahuan baru yang didapatkannya. Adapun kondisi pembelajaran harus menekankan terbentuknya aktivitas siswa di dalam maupun di luar kelas. Aktivitas yang diciptakan itu harus beragam mencakup berbagai macam kegiatan yang dapat dilakukan siswa seperti kegiatan inkuiri, eksplorasi, ekspansi, eksplanasi, dan evaluasi.

Landasan teoritis pembelajaran kooperatif adalah teori pedagogi yang dikembangkan Dewey (1916), teori relasi yang dikembangkan Alport, dan teori belajar melalui pengalaman. Ketiga landasan teori tersebut saling berkaitan secara konseptual dalam pengembangan pembelajaran kooperatif saat ini. Dalam teorinya, Dewey menyatakan bahwa kelas seharusnya mencerminkan masyarakat yang lebih besar dan berfungsi sebagai laboratorium untuk belajar tentang kehidupan nyata (Ibrahim, 2000:12). Untuk itu, siswa harus belajar hidup secara demokratis di dalam masyarakatnya. Selaras dengan pandangan tersebut, Alport menyatakan bahwa perpecahan antar-ras dan etnis tidak dapat dicegah hanya dengan mengandalkan hukum saja, tetapi kondisi 
tertentu, yaitu kontak langsung antaretnik, bersama-sama mengambil peran dalam latar tertentu, dan latar itu mendapat persetujuan antaretnis tersebut.

Landasan empirik pembelajaran kooperatif adalah berupa hasil-hasil penelitian dan pendapat para ahli tentang pembelajaran kooperatif dan pelaksanaannya dalam lapangan. Slavin (2010) telah menelaah empat puluh lima laporan penelitian tentang pengaruh pembelajaran kooperatif terhadap hasil belajar. Hasil telaah tersebut menunjukkan bahwa penggunaan teknik-teknik pembelajaran kooperatif lebih unggul dalam meningkatkan hasil belajar dibandingkan dengan belajar pengalaman belajar individual atau kompetitif (Ibrahim, 2000:16). Sejumlah penelitian lainnya juga menunjukkan bahwa pembelajaran kooperatif cenderung mendorong siswa untuk berinteraksi dengan temannya selama proses pembelajaran berlangsung. Lundgren (1994) dan Nur, dkk. (1997) dalam laporan penelitiannya juga menunjukkan bahwa pembelajaran kooperatif memiliki dampak yang sangat positif terhadap siswa yang rendah hasil belajarnya. Dampak positif tersebut di antaranya adalah (1) meningkatkan pencurahan waktu pada tugas, (2) rasa harga diri menjadi lebih tinggi, (3) memperbaiki sikap terhadap pelajaran IPA di sekolah, (4) memperbaiki tingkat kehadiran siswa, (5) angka putus sekolah menjadi rendah, (6) penerimaan terhadap perbedaan individu menjadi lebih besar, (7) perilaku mengganggu menjadi lebih kecil, (8) konflik antarpribadi menjadi berkurang, (9) sifat apatis siswa menjadi berkurang, (10) terjadi pemahaman yang lebih mendalam terhadap materi pelajaran, (11) motivasi belajar siswa menjadi lebih besar, (12) hasil belajar menjadi lebih tinggi, (13) retensi siswa menjadi lebih lama, (14) serta meningkatkan kebaikan budi, kepekaan, dan toleransi (Ibrahim, 2000:18-19).

Model pembelajaran kooperatif dikembangkan berdasarkan teori belajar kooperatif kontruktivis. Hal ini terlihat pada salah satu teori Vigotsky yaitu penekanan pada hakikat sosiokultural dari pembelajaran Vigotsky bahwa fase mental yang lebih tinggi pada umumnya muncul pada percakapan atau kerjasama antara individu sebelum fungsi mental yang lebih tinggi terserap dalam individu tersebut. Implikasi dari teori Vigotsky yaitu dikehendakinya penyusunan kelas secara kooperatif. Strategi pembelajaran kooperatif ini secara umum dapat dibedakan atas dua kategori besar, yaitu pembelajaran kelompok dan pembelajaran berbasis proyek atau pembelajaran aktif (Nur dan Wikandari, 2000:38-39). Dalam pembelajaran kelompok, siswa didorong untuk bekerja sama dan saling membantu dalam mempelajari informasi atau keterampilan yang relatif telah terdefinisikan dengan baik. Sedangkan dalam pembelajaran berbasis proyek melibatkan siswa dalam kelompok untuk menyusun suatu laporan, eksperimen, atau proyek lain. Berbeda dengan kategori pertama, pembelajaran berbasis proyek ini lebih memusatkan pada masalah-masalah yang belum tersusun dengan baik.

Salah satu desain pembelajaran yang banyak melibatkan siswa dalam proses 
pembelajaran adalah pembelajaran kooperatif investtigasi kelompok. Menurut Muhsetyo (1999:73) "Dalam pembelajaran matematika, investigasi (penyelidikan) mempunyai peran yang penting untuk melatih ketrampilan dan penalaran peserta didik melalui kajian bermakna (meaningful) yang terbuka terbatas (opened exploration) ". Selanjutnya, Orton (1992:194) menyatakan bahwa "dengan investigasi siswa akan belajar aktif dan memberi kesempatan pada siswa untuk berpikir sendiri". Pembelajaran investigasi kelompok memberikan kesempatan kepada masing- masing kelompok untuk mengamati, menganalisis, mendiskusikan, dan mengambil kesimpulan (Isjoni, 2009 : 58-59).

Setiapk kelompok diharapkan dapat saling berkomunikasi dengan baik dalam menyampaikan ide dan gagasan. Hasil akhir dari kelompok merupakan hasil dari pemikiran semua anggota kelompok yang pada dasarnyaakan lebih mengasah kemampuan intelektual siswa dibandingkan dengan belajar individual.

Beberapa ciri esensial investigasi kelompok sebagai pendekatan pembelajaran adalah (a) siswa bekerja dalam kelompokkelompok kecil; (b) kegiatan-kegiatan siswa terfokus pada upaya menyelesaikan masalah atau menjawab pertanyaan yang telah dirumuskan; (c) kegiatan belajar siswa akan selalu mensyaratkan untuk selalu mengumpulkan sejumlah data atau informasi, menganalisisnya, dan mencapai beberapa kesimpulan; (d) siswa akan menggunakan pendekatan dan bahan belajar yang beragam di dalam belajar; (e) hasil-hasil dari diskusi kelompok siswa dipertukarkan di antara seluruh siswa.

Pembelajaran investigasi kelompok memuat enam tahapan kegiatan dalam proses pembelajaran yaitu tahap pengelompokan, tahap perencanaan, tahap investigasi, tahap pengorganisasian, tahap presentasi, dan tahap evaluasi (Slavin, 2008: 218). Kelompok yang dibentuk beranggotakan masing- masing 4-5 orang, kelompok yang dibentuk bersifat heterogen baik secara kemampuan maupun jenis kelamin. Kelompok dengan anggota yang berbeda kemampuan memungkinkan terjadi transfer pengetahuan yang lebih baik.

\section{METODE PENELITIAN}

Penelitian tindakan kelas (PTK) adalah suatu bentuk kegiatan refleksi yang dilakukan oleh para pelaku pendidikan dalam suatu situasi kependidikan untuk memperbaiki rasionalitas dan keadilan tentang: praktik-praktik kependidikan, pemahaman tentang praktik-praktik tersebut, dan situasi di mana praktik-praktik tersebut dilaksanakan (Kunandar,2008:46). Selanjutnya Wardani (2003), mendefinisikan penelitian tindakan kelas adalah suatu penelitian yang dilakukan oleh guru atau seseorang tertentu di dalam kelas dengan tujuan untuk memperbaiki kinerja sebagai guru sehingga hasil belajar siswa menjadi meningkat.

Penelitian tindakan kelas mempunyai beberapa karakteristik, yaitu (1) penelitian berawal dari permasalahan praktis yang dialami oleh guru dalam melaksanakan tugas sehari-harinya sebagai pengelola pembelajaran di dalam kelas (an inquiry of practice from within), (2) penelitian melalui 
refleksi diri artinya lebih menekankan pada proses pemikiran kembali (refleksi) terhadap proses dan hasil penelitian secara berkelanjutan untuk mendapatkan penjelasan dan justifikasi tentang kemajuan, peningkatan, kemunduran, kekurangefektifan dan sebagainya dari pelaksanaan sebuah tindakan untuk dapat digunakan memperbaiki proses tindakan pada siklus-siklus selanjutnya (selfreflective inquiry), (3) fokus penelitian berupa kegiatan pembelajaran, dan (4) bertujuan untuk memperbaiki pembelajaran (Wardani, 2003:13).

Penelitian ini berangkat dari permasalahan yang diperoleh peneliti melalui serangkaian langkah pada saat observasi awal. Berdasarkan hasil observasi awal diperoleh beberapa masalah dalam proses pembelajaran yang selama ini telah dijalankan di kelas. Selanjutnya peneliti merefleksi dan menganalisis permasalahan yang ada dengan beberapa teori yang mendukung untuk mencari solusi masalah. Dalam penelitian ini, yang menjadi fokus utamanya adalah kegiatan pembelajaran dan berupaya untuk memperbaiki pembelajaran. Hal ini sesuai dengan karakteristik PTK, yaitu ingin memperbaiki pembelajaran pada materi barisan dan deret dengan penerapan pembelajaran kooperatif investigatif. Jadi, jenis penelitian yang digunakan dalam penelitian ini adalah penelitian tindakan kelas.

Adapun prosedur PTK yang akan diterapkan dalam penelitian ini akan mengacu pada model Kemmis dan Mc Taggart. Langkah-langkah tersebut berupa siklus yang terdiri dari empat tahap, yaitu: perencanaan (plan), pelaksanaan tindakan (action), pengamatan (observation), dan refleksi (reflection).

Penelitian ini dilaksanakan untuk memperbaiki praktek pembelajaran di kelas sebanyak 2 (dua) siklus. Penelitian ini dilaksanakan di SMP Negeri 1 Tembilahan pada kelas IX.9 dengan jumlah siswa 32 orang yang terdiri dari 15 laki-laki dan 17 perempuan. Penelitian ini telah dilaksanakan pada semester ganjil tahun pelajaran 2018/2019. Penelitian ini dilaksanakan dalam dua siklus, yag bertujuan untuk mengetahui peningkatan hasil belajar matematika siswa. Secara garis besar terdapat empat tahapan tindakan yang dikembangkan oleh Kemmis dan Taggart yaitu perencanaan, pelaksanaan tindakan, pengamatan, dan refleksi.

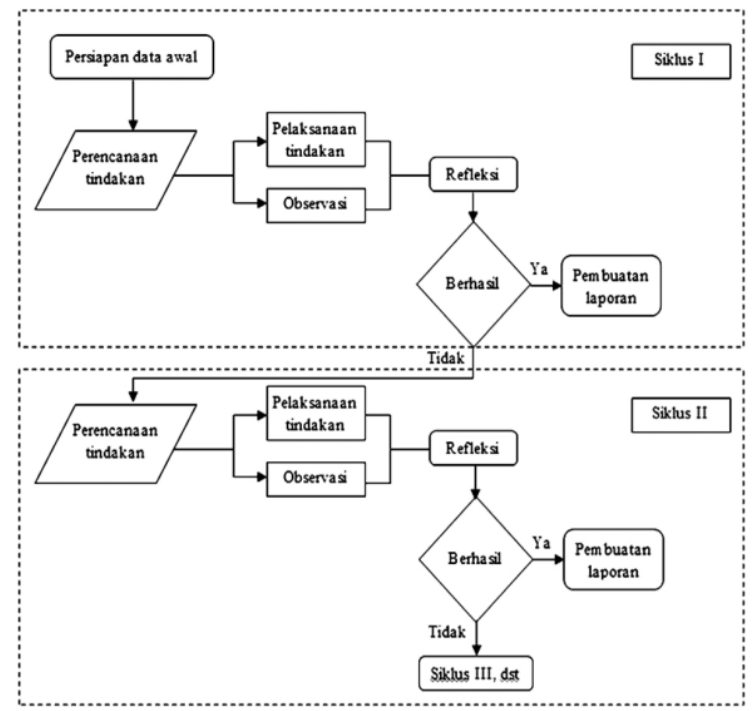

Gambar 2. Siklus Penelitian Tindakan Kelas yang Dikembangkan Kemmis dan Taggart

Dalam penelitian ini ada beberapa instrumen yang digunakan, yaitu rencana 
pelaksanaan pembelajaran (RPP), lembar kerja siswa (LKS), lembar observasi, tes kemampuan koneksi matematis. Untuk menganalisis tingkat keberhasilan setelah proses belajar mengajar setiap akhir siklus dilakukan dengan cara memberikan evaluasi berupa soal tes kemampuan koneksi matematis pada setiap akhir siklus.

\section{HASIL DAN PEMBAHASAN}

Sebelum melaksanakan penelitian, peneliti melakukan validasi perangkat pembelajaran dan instrumen penelitian yang akan digunakan. Perangkat pembelajaran dan instrumen penelitian divalidasi oleh dua orang validator. Adapun hasil validasi perangkat pembelajaran dan instrumen penelitian dari setiap validator dapat dilihat pada tabel berikut :

Tabel 1. Hasil Validasi Perangkat Pembelajaran dan Instrumen Penelitian

\begin{tabular}{|c|c|c|c|c|c|}
\hline \multirow{2}{*}{$\begin{array}{l}\text { Perangkat } \\
\text { Pembelajaran } \\
\text { dan Instrument } \\
\text { Penelitian }\end{array}$} & \multicolumn{3}{|c|}{ Validator } & \multirow{2}{*}{$\begin{array}{l}\text { Persentas } \\
\text { e Skor } \\
\text { Rata-rata }\end{array}$} & \multirow[t]{2}{*}{ Kriteria } \\
\hline & $V_{l}$ & $V_{2}$ & $V_{2}$ & & \\
\hline $\begin{array}{l}\text { Rencana } \\
\text { Pelaksanaan } \\
\text { Pembelajaran } \\
\text { (RPP) }\end{array}$ & $\begin{array}{l}79.5 \\
\%\end{array}$ & $\begin{array}{l}84.1 \\
\%\end{array}$ & $\begin{array}{l}89 . \\
8 \%\end{array}$ & $84.47 \%$ & Valid \\
\hline $\begin{array}{l}\text { Lembar Kerja } \\
\text { Siswa (LKS) }\end{array}$ & $\begin{array}{l}76.4 \\
\%\end{array}$ & $\begin{array}{l}88.9 \\
\%\end{array}$ & $\begin{array}{l}91 . \\
7 \%\end{array}$ & $85.67 \%$ & $\begin{array}{l}\text { Sangat } \\
\text { Valid }\end{array}$ \\
\hline $\begin{array}{l}\text { Lembar } \\
\text { Observasi } \\
\text { Aktivitas Siswa }\end{array}$ & $\begin{array}{l}79.2 \\
\%\end{array}$ & $\begin{array}{l}86.1 \\
\%\end{array}$ & $\begin{array}{l}90 . \\
3 \%\end{array}$ & $85.2 \%$ & $\begin{array}{l}\text { Sangat } \\
\text { Valid }\end{array}$ \\
\hline $\begin{array}{l}\text { Lembar } \\
\text { Observasi } \\
\text { Aktivitas Guru }\end{array}$ & $\begin{array}{l}77.8 \\
\%\end{array}$ & $\begin{array}{l}83.3 \\
\%\end{array}$ & $\begin{array}{l}88 . \\
9 \%\end{array}$ & $83.3 \%$ & Valid \\
\hline $\begin{array}{l}\text { Pedoman } \\
\text { Wawancara }\end{array}$ & $\begin{array}{l}79.2 \\
\%\end{array}$ & $\begin{array}{l}82.3 \\
\%\end{array}$ & $\begin{array}{l}86 . \\
1 \%\end{array}$ & $82.5 \%$ & Valid \\
\hline $\begin{array}{l}\text { Soal Tes Hasil } \\
\text { Belajar Siswa }\end{array}$ & $\begin{array}{l}90.6 \\
\%\end{array}$ & $\begin{array}{l}87.5 \\
\%\end{array}$ & $\begin{array}{l}93 . \\
8 \%\end{array}$ & $90.6 \%$ & $\begin{array}{l}\text { Sangat } \\
\text { Valid }\end{array}$ \\
\hline
\end{tabular}

Proses validasi dilaksanakan secara langsung sehingga masukan dan kritikan untuk perbaikan perangkat pembelajaran dan instrumen penelitian diterima pada waktu itu juga. Pada saat proses validasi berlangsung, validator memberikan saran baik secara tertulis maupun lisan. Validator menyarankan bahwa sebiknya hal- hal yang menjadi acuan validasi bersifat lebih khusus sehingga dapat mencerminkan perangkat pembelajaran dan instrumen penelitian. LKS harus dibuat lebih teliti dan menarik lagi sehingga setiap tindakan dapat tergambar dengan jelas. Setelah mendapat saran dan masukan dari validator, peneliti segera melakukan perbaikan terhadap perangkat pembelajaran dam instrumen penelitian. Berdasarkan hasil validasi yang diperoleh dari kedua validator menunjukkan bahwa perangkat pembelajaran dan instrumen penelitian layak digunakan dalam penelitian.

Proses pembelajaran diikuti oleh 32 siswa dengan alokasi waktu 2 x 40 menit dan 3 x 40 menit. Tindakan yang diberikan berupa pemberian soal dan selesaian dengan melakukan penyelidikan permasalahan yang disiapkan peneliti. Pembelajaran kooperatif investigasi kelompok dengan langkahlangkah sebagai berikut:

\section{Tahap Pengelompokan}

Pada tahap pengelompokan, peneliti membagi siswa dalam kelompok belajar, di mana sebelumnya peneliti telah mendistribusikan ke-32 siswa IX.9 ke dalam 8 (delapan) kelompok, masing- masing kelompok terdiri atas 4 (empat) siswa. Kelompok siswa yang dibentuk bersifat heterogen berdasarkan tingkat kemampuan 
dan jenis kelamin. Hal ini sesuai dengan ciriciri pembelajaran kooperatif yang diungkapkan oleh Subanji (2013: 160) yang menyatakan bahwa kelompok dibentuk secara heterogen, berkemampuan tinggi, sedang, dan rendah. Kelompok diupayakan terdiri atas ras, budaya, suku, dan jenis kelamin yang berbeda.

Pemilihan kelompok sebanyak 4 siswa didasarkan pada alasan, jika satu kelompok hanya terdiri dari 2 anggota, maka interaksi antar anggota kelompok akan sangat terbatas dan kelompok menjadi terhenti jika salah satu anggotanya absen. Sebaliknya, jika ukuran kelompok terlalu besar maka akan sulit bagi kelompok itu berfungsi secara efektif. Siswa yang vokal akan cenderung menguasai dan siswa yang pendiam akan cenderung mengamini saja. Dalam kelompok yang mempunyai anggota sangat besar, sukar bagi setiap siswa untuk mengutarakan pendapat-pendapat dan dalam melakukan kerja sama.

\section{Tahap Perencanaan}

Pada tahap perencanaan, setelah kelompok siswa diberi lembar kerja siswa (LKS) kelompok siswa diminta memilih topik permasalahan yang akan diselidiki. Kelompok siswa sangat senang diminta untuk menentukan permasalahan yang ingin diselidiki. Setelah kelompok siswa yakin dengan topik permasalahan yang dipilih, siswa mulai merencanakan penyelidikan. Kelompok siswa langsung membuat perencanaan mengumpulkan informasi di buku matematika lain tentang hal- hal yang terkait dengan penyelidikan. Kelompok siswa berdiskusi bagaimana dara menyelidikinya dengan berbagi tugas dalam menyelesaikan penyelidikan dan akhirnya mendapat gambaran tujuan dari penyelidikan tersebut. Karena dalam pembelajaran ini kelompok siswa diminta membuat penyelesaian berdasarkan penyelidikan tentang permasalahan yang diberikan.

\section{Tahap Investigasi}

Pada tahap investigasi, kelompok siswa melakukan penyelidikan pada permasalahan yang dipilih pada lembar kerja siswa (LKS). Siswa diminta mencari dan mengumpulkan informasi yang ada pada permasalahan untuk selanjutnya dari informasi tersebut siswa menyelesaikan soal sebanyak mungkin terkait permasalahan. Pada tahap investigasi ini, siswa mampu menggunakan pengetahuannya ketika membuat penyelesaian soal, setelah menyelesaiakan masalah ide- ide tersebut muncul sesuai dengan kreativitas siswa dalam diskusi kelompok karena siswa bekerja secara bebas dan berkelompok. Guru hanya bertindak sebagai motivator dan fasilitator yang memberikan dorongan kepada siswa untuk mengungkapkan pendapat dan menuangkan pemikirannya serta menggunakan pengetahuan dalam membuat soal dan penyelesaiannya. Guru juga berperan dalam mendorong siswa untuk dapat memperbaiki hasil kerja kelompok. Dengan demikian, guru harus selalu menjaga suasana belajar agar investigasi tidak terhenti di tengah jalan dengan mendorong siswa menghubungkan pengetahuan yang dimiliki.

Seperti pernyataan Ausubel yang menyatakan bahwa belajar bermakna timbul jika siswa mencoba menghubungkan 
pengetahuan baru dengan pengetahuan yang dimilikinya. Siswa diberikan kebebasan untuk mengungkapkan ide dan kreativitasnya. Dengan demikian, siswa membentuk pengetahuan sendiri bersama dengan kelompoknya secara aktif. Hal ini mendukung pendapat Glasersfeld (1989), siswa belajar dengan membangun dan restrukturisasi pengetahuan mereka sendiri. Demikian pula, Van de Walle, dkk (2009) menyatakan bahwa siswa sering membongkar dan menemukan konsepkonsep matematika selama proses belajar mengajar untuk mengkonstruksi pengetahuan.

\section{Tahap Pengorganisasian}

Siswa menyiapkan penyelesaian dari hasil investigasi untuk dipresentasikan. Siswa mulai merencanakan apa yang akan dipresentasikan dan bagaimana cara mempresentasikannya. Ketua kelompok membagi anggota kelompoknya untuk menjadi notulen, penyaji dan secara bergantian dalam menjawab pertanyaan tanggapan dari kelompok lain.

\section{Tahap Presentasi}

Setelah diskusi kelompok, kegiatan selanjutnya adalah mempresentasikan hasil kerjanya di depan kelas atau diskusi kelas. Pada diskusi kelas ini diberikan kesempatan kepada salah satu perwakilan kelompok siswa untuk mempresentasikan hasil kerja kelompoknya. Hal ini diperlukan untuk dapat memupuk keberanian siswa dalam menyampaikan pendapatnya. Langkah ini sangat diperlukan agar siswa dapat menerima masukan dari orang lain, tetapi siswa juga mampu untuk mempertahankan pendapatnya jika menurut pendapat mereka masukan tersebut tidak logis. Dalam diskusi ini, memungkinkan adanya pembetulan kesalahan yang dilakukan oleh kelompok yang mempresentasikan. Jawaban-jawaban yang salah dikoreksi oleh kelompok lain dengan cara bertanya atau sanggahan. Koreksi yang diberikan kelompok lain dan mengamati penyajian kelompok lain saat sharing sangat berguna untuk memperbaiki kesalahan yang dilakukan suatu kelompok. Hal ini mendukung pendapat Sutawidjaja (2002:358) bahwa ketika kelompok menyajikan laporannya (benar atau salah), kelompok akan mempunyai kesempatan berharga untuk memperbaiki laporan mereka.

\section{Tahap Evaluasi}

Sebelum pelaksaan evaluasi guru bersama siswa membuat kesimpulan terhadap pembelajaran yang baru saja dilakukan. Guru perlu memastikan bahwa siswa memahami materi yang baru saja dipelajari. Sebagai penutup, atas arahan dan bimbingan guru siswa menuliskan hasil diskusinya sebagai simpulan akhir pembelajaran. Hal ini didukung pendapat Degeng (1997) bahwa membuat rangkuman atau kesimpulan dari apa yang telah dipelajari perlu dilakukan untuk mempertahankan retensi. Setelah siswa merangkum dan mencatat setiap materi yang disajikan. Siswa menggabungkan tiap materi yang diinvestigasi dalam kelompoknya dan kelompok lain. Guru memberikan penekanan dan menjelaskan kembali langkah-langkah yang dianggap sulit oleh siswa. Setelah proses pembelajaran selesai, untuk melihat keberhasilan tiap-tiap kelompok pada proses 
pembelajaran, siswa diminta mengerjakan soal latihan secara individu.

Pada tahap kegiatan akhir guru bersama siswa melakukan refleksi pembelajaran. Siswa merasa senang belajar berkelompok dan meminta kepada peneliti bahwa waktu untuk membuat soal dan penyelesaian diperpanjang, karena kelompok siswa berlomba membuat soal sebanyakbanyaknya. Guru mengucapkan terima kasih kepada siswa dan meminta ketua kelas untuk memimpin doa. Setelah pembacaan doa selesai, guru mengingatkan kepada siswa untuk mempersiapakan diri untuk pertemuan selanjutnya dan menutup pembelajaran.

Hasil pengamatan pada tahap pengelompokan yang dilakukan pada siklus I, siswa sangat senang saat diminta untuk menentukan sendiri permasalahan yang ingin diselidiki. Pada tahap perencanaan, setelah diberi lembar kerja siswa (LKS) siswa langsung mencari informasi dengan membuka buku yang dimiliki, berdiskusi untuk berbagi tugas dalam penyelesaian. Tahap penyelidikan siswa berperan aktif dalam menyelidiki permasalahan yang dipilih. Dari informasi yang diperoleh dalam penyelidikan, siswa menuliskan informasi yang terdapat pada permasalahan, selanjutnya membuat soal dan menyelesaikan terkait masalah yang dipilih. Siswa berbagi peran, ada yang menulis informasi, ada yang berdiskusi menulis soal dan penyelesaiannya, guru membimbing siswa jika mengalami kesulitan. Pada tahap pengorganisasian, ketua kelompok bingung membagi tugas untuk tampil di depan kelas karena belum terbiasa. Tahap presentasi, kebanyakan siswa takut untuk tampil, akhirnya ada dua kelompok yang maju setelah diadakan pengundian. Saat diskusi kelas berjalan dengan baik, banyak pertanyaan dan saran yang muncul. Pada tahap evaluasi, siswa serius memperhatikan saat guru menjelaskan langkah-langkah yang dianggap sulit pada saat investigasi berlangsung. Pada waktu mengerjakan latihan, siswa masih terlihat belum dapat menyelesaikan semua soal, pengerjaan hanya dikerjakan sebagian siswa dalam kelompok.

Pada proses pembelajaran, materi yang dibahas siswa pada siklus I tidak terlalu rumit, akan tetapi siswa belum terbiasa dengan pembelajaran koopertaif investigasi kelompok. Akibatnya perlu waktu yang lama saat siswa melakukan penyelidikan, mebuat soal dan penyelesaiannya. Pada diskusi kelas siswa sangat aktif, banyak pertanyaan dan saran yang muncul, akan tetapi yang menjawab pertanyaan didominasi ketua kelompok. Walaupun diskusi kelas berjalan lancar tetapi dalam menjawab pertanyaan tidak merata, sehingga kurang sekali kebersamaan kelompok pada saat presentasi. Hal ini dikarenakan anggota yang lain masih gugup, belum terbiasa dan kurang percaya diri berbicara di depan kelas.

Pada siklus II, siswa lebih aktif dibanding siklus I dan sudah bisa bekerja lebih cepat, tidak ada anggota kelompok yang pasif,siswa mulai terbiasa bertanya kepada guru ketika mengalami kesulitan. Pada saat presentasi ke depan kelas, semua kelompok ingin tampil mempresentasika hasil di depan kelas. Pada saat diskusi kelas, pertanyaan atau saran yang muncul tidak 
sebanyak pada siklus I, karena siswa sudah terbiasa dan memahami prosedur pembuatan soal dan penyelesaiannya. Kelompok yang tampil mempresentasikan sudah kelihatan kebersamaanya, pertanyaan yang muncul dijawab secara bergantian. Guru memberi bantuan pada siswa dengan menggali informasi dari siswa. Akhirnya tiap kelompok bisa melaksanakan pembelajaran kooperatif investigasi kelompok dengan baik. Pada siklus II, analisis hasil tes akhir siklusmenunjukkan peningkatan

kemampuan koneksi matematis siswa. Hal ini terlihat pada hasil jawaban siswa yang dapat menyelesaikan soal tes dengan baik, walaupun masih terdapat kesalahankesalahan kecil perhitungan. Akan tetapi, semua siswa mampu mendapatkan skor di atas Kriteria Ketuntasan Minimum (KKM) yaitu $\geq 76$. Dari analisi hasil tes, pada siklus I rata- rata kemampuan koneksi matematis siswa adalah $70.97 \%$ di mana hanya 22 dari

31 siswa yang kemampuan koneksi matematisnya di atas 76. Pada siklus II, ratarata kemampuan koneksi matematis siswa mencapai $93.55 \%$ di mana 29 dari 31 siswa tuntas dan mendapat skor hasil tes kemampuan koneksi matematis di atas 76. Terjadi peningkatan kemampuan koneksi matematis siswa dari siklus I ke siklus II. Persentase ketuntasan belajar siswa pada siklus II sudah memenuhi kriteria keberhasilan pada penelitian ini. Maka dapat disimpulkan pelaksanaan pembelajaran kooperatif investigasi kelompok dapat meningkatkan kemampuan koneksi matematis siswa.

\section{SIMPULAN}

Dari hasil penelitian, kemampuan koneksi matematis siswa meningkat dengan pembelajaran kooperatif investigasi kelompok. Siswa mampu mengaitkan ide-ide matematika sebelum, selama dan setelah membuat soal dan penyelesaian. Ide-ide koneksi matematis siswa sering muncul setelah siswa menyelesaikan masalah. Ide membuat soal baru dan penyelesaian tersebut dengan menambah informasi yang terdapat pada permasalahan yang diberikan. Hal ini didukung dengan persentase hasil tes kemampuan koneksi matematis siswa secara klasikal yang mendapatkan skor $\geq 76$ terjadi peningkatan yaitu $77.42 \%$ pada siklus I menjadi $93.55 \%$ pada siklus II. Persentase hasil observasi aktivitas guru meningkat dari $85.33 \%$ pada siklus I menjadi $95.66 \%$ pada siklus II. Persentasi hasil observasi aktivitas siswa meningkat dari $82.44 \%$ pada siklus I menjadi $91.27 \%$ pada siklus II. Hal ini menunjukkan bahwa aktivitas guru dan siswa pada pembelajaran kooperatif investigasi kelompok berjalan dengan sangat baik. Respon siswa terhadap pembelajaran kooperatif investigasi kelompok pada penelitian ini sangat positif.

Berdasarkan hasil penelitian dan kesimpulan di atas, maka peneliti dapat menyarankan hal- hal sebagai berikut :

a. Bagi siswa dalam pembelajaran kooperatif investigasi kelompok diharapkan dapat mengeksplor pengetahuan yang dimiliki dan mengkoneksikan pengalaman belajar untuk dapat saling menghargai, 
bekerjasama, aktif dalam diskusi kelompok dan diskusi kelas.

b. Untuk meningkatkan kemampuan koneksi matematis siswa, guru dapat menerapkannya pembelajaran kooperatif investigasi kelompok pada materi lainnya.

c. Bagi peneliti yang inin menerapkan pembelajaran kooperatif investigasi kelompok sebaiknya merencanakan alokasi waktu sebaik mungkin, sehingga tahapan- tahapan pembelajaran terlaksana dengan baik.

\section{DAFTAR PUSTAKA}

Akdon. 2008.Aplikasi Statistika dan Metode

Penelitian untuk Administrasi dan Manejemen. Bandung: Dewa Ruchi. Arikunto, Suharsimi, dkk 2008. Penelitian

Tindakan Kelas. Jakarta: PT. Bumi Aksara

Depdiknas. 2006. Standar Kompetensi Mata Pelajaran Matematika Sekolah Menengah Pertama dan Madrasah Tsanawiyah. Jakarta

Djamarah, Bahri dan Zein, Ahmad. 2002. Psikologi Belajar. Jakarta: PT. Rineka Cipta

Hasan Jismulatif, Marzuki. (2017). An Analysis of Student's Ability in Writing at Riau University Pekanbaru Indonesia. Theory and Practice in Language Studies, Vol. 7, No. 5, DOI:

http://dx.doi.org/10.17507/tpls.0705. $\underline{08}$

Isjoni, 2007. Cooperative Learning: Efektifitas Pembelajaran Kelompok. Bandung: Alfabeta
Mulyasa. 2009. Praktik Penelitian Tinakan Kelas. Bandung: Remaja Rosdakarya

Nurani, Yuliani, dkk. 2003. Strategi Pembelajaran. Jakarta : Pusat Penerbitan Universitas Terbuka.

Purwanto, Ngalim. 2006. Prinsip-Prinsip dan Teknik Evaluasi Pengajaran. Bandung: PT. Remaja Rosdakarya

Sabri, Ahmad. 2007. Strategi Belajar Mengajar Micro Teaching. Ciputat : PT Ciputat Press.

Sanjaya, Wina. 2008. Kurikulum dan Pembelajaran.Jakarta:Kencana Prenada media group. 2009.Penelitian Tindakan Kelas.Jakarta:Kencana Prenada media group.

Sardiman. 2010. Interaksi dan Motivasi Belajar Mengajar. Jakarta: Raja Grafindo Persada

Slavin, Robert, E. 1995. Cooperative Learning Theory Reasearch and Practice. Baston Ally and Bacon 2008. Cooperative Learning Lie, Anita. 2007. Cooperative Learning: Memperaktikkan Cooperatif Learning di Ruang-Ruang Kelas. Jakarta: Grasindo

Mudjiono, Dimyati. 2006. Belajar dan Pembelajaran. Jakarta: Rineka Cipta.

Teori, Riset, dan Praktek.Bandung:Nusa Media.

Sriyanto,HJ. 2007. Strategi Sukses Menguasai matematika.

Yogyakarta: Indonesia Cerdas. Sudjana, Nana, 1991. Penilaian Hasil Proses Belajar Mengajar. Bandung: Remaja Rosdakarya 
Anita

Suherman dkk, Erman. 2001. Strategi KELAS IX SMP NEGERI 1 TEMBILAHAN

PembelajaranMatematika

Kontemporer. Bandung: JICA

Universitas

Pendidikan

Indonesia 

MENINGKATKAN HASIL BELAJAR MATEMATIKA SISWA KELAS IX SMP NEGERI 1 TEMBILAHAN 